\title{
Ethnic disparities in breast cancer between Central Europe Caucasian women of Slavic origin and Middle East Turkish subjects
}

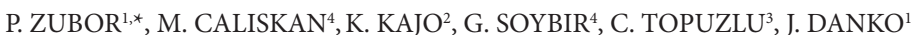

${ }^{1}$ Department of Obstetrics and Gynecology, Jessenius Medical Faculty, Comenius University, Kollarova 2, 03659 Martin, Slovak Republic; ${ }^{2}$ Department of Pathology, Jessenius Medical Faculty, Comenius University, Kollarova 2, 03659 Martin, Slovak Republic; ${ }^{3}$ Istanbul University Oncology Institute, Department of Surgical Oncology, millet cad., 34100 Capa Istanbul, Turkey; ${ }^{4}$ Department of General Surgery, Umraniye Education and Research Hospital, Adem Yavuz 1, 34760 Istanbul, Turkey

${ }^{*}$ Correspondence: zubor@jfmed.uniba.sk

Received October 13, 2012 / Accepted May 20, 2013

\begin{abstract}
The biological, cultural, behavioral and sociodemographic differences across populations modulate breast cancer profile among races or ethnics. Following this, we aimed to identify differences in breast cancer epidemiology, histopathology, and clinical presentation from representatives of central Europe (Slovakia) and Middle-East countries (Turkey) to point on ethnic disparities in cancer biology.

The population based cross-sectional study analyzing 414 cases of primary breast carcinomas where 214 represented Caucasian and 200 Turkish subjects.

The differences were found for age at the time of diagnosis $(<0.0001)$, education, menopausal status $(<0.001)$, tumor localization $(<0.01)$, size $(<0.0001)$, grade $(<0.05)$ and axillary lymph node status $(<0.001)$ between groups. Although carcinomas in Slovak subjects were of higher grade, negative axillary nodal status was more frequent finding compared to Turkish patients (50.0 vs. $41.0 \%)$. The Slovak group showed carcinomas to be more often ER positive ( 72.4 vs. $54.0 \% ;<0.001)$, ER/PgR positive ( 54.6 vs. $49.0 \%$; $<0.001$ ), of better Nottingham prognostic index $(<0.001)$, and less frequent Her-2 positive (21.2 vs. $28.5 \%)$. Slovak population expressed significantly higher risk of non-sentinel lymph node metastases with increased tumor size, grade, vascular invasion and Her-2 positivity compared to Turkey population. The tumor size $>2 \mathrm{~cm}$ and high tumor grade (G3) bears a risk of $\mathrm{OR}=7.62$ and $\mathrm{OR}=3.10$ in Slovak compared to $\mathrm{OR}=3.94$ and $\mathrm{OR}=1.79$ in Turkish cases, respectively.

There are wide demographic and biological disparities in breast cancer between observed ethnics providing unique information for clinicians working at the level of screening or therapy in these populations.
\end{abstract}

Key words: breast cancer, ethnic, race, disparity, cancer biology

Breast cancer is the most frequent women malignancy worldwide [1]. All women regardless of race, ethnicity or heritage are at risk of developing this pathology. Variations in disease incidence among multicultural populations suggest that etiologic factors differ in their biologic expression and impact on disease outcome [2,3]. Key factors that affect disease development are genetic, environment, reproductive history, endogenous and exogenous hormones, immunity, and host vulnerability. Culture, sociodemographic differences, and behavioral characteristics across populations modulate biology of disease expression among different races and ethnic groups [4]. Previous research found differences in breast cancer features (e.g. grade, size, nodal status) or survival based on geographical region of residence, race/ethnicity, and socioeconomic factors [5-7]. Thus, research considering ethnicity is becoming particularly important giving the level of ethnic diversity in biological profile of carcinoma, age on onset and extent of differences among minor/major ethnic groups across Europe in closer view.

Cancer prevalence in central Europe is increasing [8] and we live the great socio-economic-political changes of limitless international migration and forming one pan-European region. Migration within Europe is on-going social phenomenon of large scale, which affects the health of individual migrants, as well as populations [9]. At this time, except West-European or US studies, data reporting differences in biological features 
of breast carcinomas for women from other European/Asian (racial/ethnic) populations/groups are scarce [10]. Thus, we decided to conduct a comparative study including two (frequently overlook) populations of which large communities in several European countries are established, (e.g. 1.7 million Turkish population in Germany forming the largest group $125.8 \%$ / among non-German residents, and over 0.8 millions Slovak people in central European countries) [11,12].

The aim of this study was to identify differences between breast cancer epidemiology, histopathology, aggressiveness and clinical presentation from representatives of central Europe and Middle-East countries (Slovakia and Turkey), in effort to point on ethnic disparities in cancer biology among female populations. A study has also an ambition to help health care providers in planning preventive activities and determining individual therapy, when patient of such ethnicity/race is managed on background of different domestic population.

\section{Material and methods}

Specimen collection. This was a retrospective study including primary invasive female breast carcinomas $(n=452)$ operated at co-worked institutions both randomly selected from the hospital registers. The cases with known disease stage, histological grade, hormonal receptor and Her-2 status were included. Patients after neoadjuvant therapy, carcinomas in situ, medullary and lobular carcinomas were excluded from correlations due to inability of histological grading [13]. Subsequently a total of 414 cases entered final analyses of which 214 cases represented Slovak and 200 Turkish subjects. Based on retrospective analysis of clinical outcomes, no specific written informed consent was required. However, the process of data collection was conducted in compliance with ethical requirements of each of participating institutions (IRB 423/2008).

Histologic examination. Histological assessments were performed on 4-5 $\mu \mathrm{m}$ thick hematoxylin and eosin stained sections of formalin-fixed, paraffin-embedded tumors. Typing was evaluated according to the WHO Classification of Tumours [14], and histological grading as presented by Elston and Ellis [15].

Immunohistochemical analysis. Tissue sections $(4-5 \mu \mathrm{m}$ thick) from paraffin blocks were used for immunohistochemical analyses. For detection of estrogen receptors (ER) we used anti-ER (clone ER1D5, Immunotech) and for detection of progesterone receptors (PR) we used anti-PR (clone 1A6, Immunotech). The ER and PR status was interpreted semiquantitatively as positive when $>10 \%$ of tumor cells showed positive nuclear staining. Her-2 immunohistochemical status was initially analyzed by HercepTest (DakoCytomation, Glostrup). The results were interpreted as follows: $0=$ no membrane staining (MS); $1+=$ faint, partial MS; $2+=$ weak complete MS in more than $10 \%$ of invasive cancer cells; $3+=$ intense complete MS in more than $10 \%$ of invasive cancer cells. Patients with $2+$ results were re-examined by FISH.
Fluorescence in situ hybridization (FISH). For FISH study $4-\mu \mathrm{m}$ thick sections of formalin-fixed paraffin-embedded tissue mounted on silanized slides were used. The ONCOR HER-2/neu Gene Detection System (Ventana Medical System) was used. FISH methodology and results interpretation was used as described previously [16]. For scoring of signals was epifluorescence microscope was used. Signals from 40 randomly selected cancer nuclei from two distinct areas were enumerated. A mean signal of $>4$ indicated Her- 2 amplification, whereas signal $\leq 4$ indicated that Her-2 gene amplification was not identified.

Statistical analysis. The chi-square (two-tailed) statistic was used to examine categorical variables and associations between clinico-pathological characteristics in univariate analysis. An independent sample $\mathrm{t}$-test was used to compare the mean of two samples, and the Mann-Whitney test was used to test the difference between two independent samples. For assessment of probability of non-sentinel lymph node involvement we applied the Odds ratio (OR) and a 95\% confidence interval $(95 \% \mathrm{CI})$ obtained from unconditional logistic regression. The $\mathrm{P}$ value $<0.05$ was considered significant. All statistics were performed with MedCalc 12.1.4 (MedCalc ${ }^{\circledR}$ Inc., Mariakerke, Belgium) software.

\section{Results}

The study population consisted of 414 women with verified histology of breast carcinoma divided in two groups. 214 cases represented sample of Caucasian (Slovak) women ranging in age from 33 to 98 years (mean 59.3) and 200 patients belonged to Turkish population in age from 30 to 80 years (mean 53.9) at the time of diagnosis, respectively. The significant differences were found for age at the diagnosis $(<0.0001)$, education level, menopausal status $(<0.001)$, and tumor localization $(<0.01)$. The majority of Slovak patients were of middle education level (62.2\%), postmenopausal status (72.9\%) and older than 50 years $(75.7 \%)$ compared to Turkish patients. Here contrary up to $12.0 \%$ (3-times more than Slovak) women had university education and carcinoma occurred more often in premenopausal (27.5\%; 2-times more) and young women before 50 years of age (45.5\%; nearly 2 -times more). In both groups carcinoma most often occurred in upper outer quadrant (Table 1).

Concerning the disease stage, we have revealed significant differences in tumor size $(<0.0001)$, grade $(<0.05)$ and axillary lymph node status $(<0.001)$, whereas difference in tumor type and peritumoral vascular invasion (PVI) was insignificant. In Turkish patients, the majority of carcinomas were $>2 \mathrm{~cm}$ $(74.0 \%)$ and only $2.0 \%$ of women has tumor smaller than $1 \mathrm{~cm}$ compared to Slovak patients (43.9\% and 30.0\%), respectively. Although carcinomas in Slovak subjects were in majority of higher grade, negative axillary lymph node status was more frequent finding compared to Turkish patients $(50.0 \%$ versus $41.0 \%$ ), Table 2.

As for the histology, data from Slovak group showed carcinomas to be significantly more often ER positive $(72.4 \%$ 
Table 1. Demographic characteristic of patients

\begin{tabular}{|c|c|c|}
\hline \multirow[t]{2}{*}{ Parameter } & \multicolumn{2}{|c|}{ Population } \\
\hline & Slovak & Turkey \\
\hline $\mathrm{n}$ & 214 & 200 \\
\hline Mean age (years) & 59 & 54 \\
\hline SD & 11.6 & 12.3 \\
\hline Age range (years) & $33-98$ & $30-80$ \\
\hline$P$ value ${ }^{\text {†* }}$ & & $<0.001^{\dagger}<0.0001^{*}$ \\
\hline Education & Value (n [\%]) & Value (n [\%]) \\
\hline Elementary & $72(33.6)$ & $84(42.0)$ \\
\hline Middle & $133(62.2)$ & $92(46.0)$ \\
\hline University & $9(4.2)$ & $24(12.0)$ \\
\hline$P$ value ${ }^{*}$ & & $<0.001$ \\
\hline \multicolumn{3}{|l|}{ Menopausal status } \\
\hline Premenopause & $28(13.1)$ & $55(27.5)$ \\
\hline Perimenopause & $30(14.0)$ & $28(14.0)$ \\
\hline Postmenopause & $156(72.9)$ & $117(58.5)$ \\
\hline Pvalue ${ }^{*}$ & & $<0.001$ \\
\hline \multicolumn{3}{|l|}{ Tumor localization } \\
\hline C50.0 & $1(0.5)$ & $0(0.0)$ \\
\hline C50.1 & $29(13.6)$ & $20(10.0)$ \\
\hline C50.2 & $42(19.6)$ & $23(11.5)$ \\
\hline C50.3 & $25(11.7)$ & $12(6.0)$ \\
\hline C50.4 & $85(39.7)$ & $120(60.0)$ \\
\hline C50.5 & $31(14.4)$ & $23(11.5)$ \\
\hline C50.6 & $1(0.5)$ & $2(1.0)$ \\
\hline C50.7 & $0(0.0)$ & $0(0.0)$ \\
\hline Pvalue ${ }^{*}$ & & $<0.01$ \\
\hline
\end{tabular}

${ }^{\dagger} \mathrm{P}$ value obtained from unpaired Student $-t$ test

${ }^{\ddagger}$ P value obtained from Mann-Whitney test

${ }^{*} \mathrm{P}$ value obtained from Chi-square test for trend (two-tailed)

Abbreviations: $\mathrm{SD}=$ standard deviation

versus $54.0 \%$; $<0.01$ ), ER/PgR positive (54.6\% versus $49.0 \%$; $<0.0001)$, of better prognosis expressed by Nottingham prognostic index $(<0.001)$, and insignificantly less frequent Her-2 positive (21.2\% versus $28.5 \%$ ) compared to Turkish patients, respectively. The intraductal component and PgR status showed no differences, table 3 . The most prominent differences were noted for Her-2 and ER status. In Slovak group a significant positive correlations between Her-2 and negative correlations between ER status and increased tumor size, tumor grade and axillary lymph node involvement were observed, whereas only ER status showed this trend in Turkish cases. Her-2 status did not show significant associations with above mentioned parameters (Table 4). Striking differences were found in univariate risk assessment of non-sentinel lymph node metastases (NSLNM) after adjustment for tumor size, grade and PVI. Slovak population expressed significantly higher risk of NSLNM with increased tumor size, grade, PVI and Her-2 positivity compared to Turkey population. For example, tumor size in cases $>2 \mathrm{~cm}$ and high tumor grade bears
Table 2. Clinico-pathological characteristic of patients

\begin{tabular}{|c|c|c|}
\hline \multirow{2}{*}{$\begin{array}{l}\text { Parameter } \\
\text { Population }\end{array}$} & \multicolumn{2}{|c|}{ Value (n [\%]) } \\
\hline & Slovak & Turkey \\
\hline $\mathrm{n}$ & 214 & 200 \\
\hline \multicolumn{3}{|l|}{ Age at diagnosis (years) } \\
\hline$\leq 50$ & $52(24.3)$ & $91(45.5)$ \\
\hline$>50$ & $162(75.7)$ & $109(54.5)$ \\
\hline$\leq 30$ & $3(1.4)$ & $14(7.0)$ \\
\hline Pvalue* & & $<0.0001$ \\
\hline \multicolumn{3}{|l|}{ Tumor size $(\mathrm{cm})$} \\
\hline$\leq 1 \mathrm{~cm}$ & $64(30.0)$ & $4(2.00)$ \\
\hline $1-2 \mathrm{~cm}$ & $56(26.1)$ & $48(24.0)$ \\
\hline$>2 \mathrm{~cm}$ & $94(43.9)$ & $148(74.0)$ \\
\hline$P$ value ${ }^{*}$ & & $<0.0001$ \\
\hline \multicolumn{3}{|l|}{ Tumor type } \\
\hline Invasive ductal & $156(72.9)$ & $156(78.0)$ \\
\hline Invasive lobular & $26(12.1)$ & $23(11.5)$ \\
\hline Other & $32(15.0)$ & $21(10.5)$ \\
\hline$P$ value * & & NS \\
\hline \multicolumn{3}{|l|}{ Tumor grade ${ }^{\dagger}$} \\
\hline 1 & $36(19.1)$ & $45(25.4)$ \\
\hline 2 & $58(30.9)$ & $62(35.0)$ \\
\hline 3 & $94(50.0)$ & $70(39.6)$ \\
\hline Pvalue* & & $<0.05$ \\
\hline \multicolumn{3}{|l|}{ Lymph nodes status } \\
\hline 0 & $107(50.0)$ & $82(41.0)$ \\
\hline 1 & $62(29.0)$ & $39(19.5)$ \\
\hline 2 & $32(14.9)$ & $52(26.0)$ \\
\hline 3 & $13(6.10)$ & $27(13.5)$ \\
\hline$P$ value * & & $<0.001$ \\
\hline \multicolumn{3}{|c|}{ Peritumoral vascular invasion } \\
\hline Absent & $104(48.6)$ & $111(55.5)$ \\
\hline Present & $110(51.4)$ & $89(44.5)$ \\
\hline$P$ value ${ }^{*}$ & & NS \\
\hline
\end{tabular}

${ }^{*} \mathrm{P}$ value obtained from Chi-square test for trend (two-tailed)

${ }^{\dagger}$ Except lobular breast cancer

Abbreviations: $\mathrm{NS}=$ not significant

a risk with an $\mathrm{OR}=7.62(95 \% \mathrm{CI}=3.66-15.90)$ and $\mathrm{OR}=3.10$ (95\%CI $=1.40-6.87)$ in Slovak women compared to $\mathrm{OR}=3.94$ $(95 \% \mathrm{CI}=2.02-7.67)$ and $\mathrm{OR}=1.79(95 \% \mathrm{CI}=0.83-2.86)$ in Turkish cases, respectively. The risk of NSLNM expressed for PVI and Her-2 positivity was more than two-fold higher in Slovak compared to Turkey subjects $\left(\mathrm{OR}_{\mathrm{PVI}}=6.03\right.$ versus $\mathrm{OR}=2.26$ and $\mathrm{OR}_{\text {Her-2 }}=2.45$ versus $\mathrm{OR}=1.5$, respectively), Table 5 .

\section{Discussion}

Several studies have analyzed mortality and survival between various ethnics/races, and differences have been noted in many of them, as well as in national cancer statistics $[2,17]$. It was proved that Asian-Americans tend to have lower incidence of breast cancer than Caucasians, and they also have a superior prognosis [18]. On the other side Hispanic women are more 
frequently diagnosed at a later stage and exhibit less favorable disease features relative to non-Hispanic Caucasians [19]. As for African-American women it was thought the carcinomas are more often diagnosed at a later stage, have less favorable characteristics, and may suffer barriers to quality care, resulting in higher mortality and poorer survival rates than Caucasian woman. It was suggested this disparity might be caused by unequal access to medical care. However, results from large studies support the theory that equal treatments produce equal outcomes [20,21]. Considering that health care is getting equal in modern medical centers, remaining differences in cancer mortality and survival rates may originate from racial/ethnic disparities in clinical, socioeconomic and biological characteristics of the disease, which suggest racial and geographical differences in the biology of disease [22]. The deeper insight into these associations could bring the molecular classification of carcinomas $[23,24]$, and detection of genes expression profiles that may serve as individual predictors of outcome and response to adjuvant therapy with high accuracy $[25,26]$. However, these techniques are not accessible for every breast cancer unit as there are still medical institutions that have to rely only on histopathology. It is the basic histological analysis (e.g. ER, PgR, Her-2 status, tumor grading) not complex geneexpression profiling that may primary revealed differences in tumor biology between ethnics/races population or predict disease aggressiveness [27,28].

Despite the evident breast cancer burden worldwide, the information about its epidemiology in different ethnic groups is difficult to obtain. This is because of the difficulty of defining and classifying people into ethnic groups and inconsistent or incomplete way of data monitoring and collection [29]. Breast cancer is the most frequent cancer
Table 3. Clinico-pathological characteristic of patients

\begin{tabular}{|c|c|c|}
\hline \multirow{2}{*}{$\begin{array}{l}\text { Parameter } \\
\text { Population }\end{array}$} & \multicolumn{2}{|c|}{ Value (n [\%]) } \\
\hline & Slovak & Turkey \\
\hline $\mathrm{n}$ & 214 & 200 \\
\hline \multicolumn{3}{|l|}{ Receptor status } \\
\hline ER positive & $155(72.4)$ & $108(54.0)$ \\
\hline ER negative & $59(27.6)$ & $92(46.0)$ \\
\hline PgR positive & $123(57.5)$ & $112(56.0)$ \\
\hline PgR negative & $91(42.5)$ & $88(44.0)$ \\
\hline Pvalue ${ }^{\star}$ & & $<0.01$ \\
\hline $\mathrm{ER}+/ \mathrm{PgR}+$ & $117(54.6)$ & $98(49.0)$ \\
\hline $\mathrm{ER}+/ \mathrm{PgR}-$ & $38(17.8)$ & $10(5.0)$ \\
\hline ER - / PgR + & $6(2.80)$ & $14(7.0)$ \\
\hline ER - / PgR - & $53(24.8)$ & $78(39.0)$ \\
\hline Pvalue * & & $<0.0001$ \\
\hline \multicolumn{3}{|l|}{ Her-2 status } \\
\hline Negative & $167(78.8)$ & $133(71.5)$ \\
\hline Positive & $45(21.2)$ & $53(28.5)$ \\
\hline Pvalue * & & NS \\
\hline \multicolumn{3}{|c|}{ Nottingham prognostic index } \\
\hline$\leq 3.4$ & $98(45.8)$ & $54(27.0)$ \\
\hline $3.5-5.4$ & $74(34.6)$ & $89(44.5)$ \\
\hline$>5.4$ & $42(19.6)$ & $57(28.5)$ \\
\hline Pvalue * & & $<0.001$ \\
\hline \multicolumn{3}{|l|}{ Intraductal component } \\
\hline Low grade & $78(36.4)$ & $85(42.5)$ \\
\hline High grade & $46(21.6)$ & $46(23.0)$ \\
\hline None & $90(42.0)$ & $69(34.5)$ \\
\hline Pvalue * & & NS \\
\hline
\end{tabular}

${ }^{*} \mathrm{P}$ value obtained from Chi-square test (two-tailed)

Abbreviations: $\mathrm{NS}=$ not significant; $\mathrm{ER}=$ estrogen receptor; $\mathrm{PgR}=$ progesterone receptor

Table 4. Correlations between clinico-pathological factors and molecular predictive markers

\begin{tabular}{|c|c|c|c|c|c|c|c|c|}
\hline \multirow[t]{3}{*}{ Population } & \multicolumn{4}{|c|}{ Slovakian } & \multicolumn{4}{|c|}{ Turkey } \\
\hline & \multicolumn{2}{|c|}{ Her-2 status } & \multicolumn{2}{|c|}{ Estrogen Receptor } & \multicolumn{2}{|c|}{ Her-2 status } & \multicolumn{2}{|c|}{ Estrogen Receptor } \\
\hline & Positive/total (\%) & $P$ value ${ }^{*}$ & Positive/total (\%) & $P$ value ${ }^{*}$ & Positive/total (\%) & $P$ value ${ }^{*}$ & Positive/total (\%) & $P$ value $^{*}$ \\
\hline \multicolumn{9}{|c|}{ Tumor size $(\mathrm{cm})$} \\
\hline$\leq 1 \mathrm{~cm}$ & $9 / 63(14.3)$ & $<0.01$ & $53 / 64(82.8)$ & $<0.01$ & $1 / 4(25.0)$ & NS & $1 / 4(25.0)$ & $<0.05$ \\
\hline $1-2 \mathrm{~cm}$ & $7 / 56(12.5)$ & & $43 / 56(76.8)$ & & $11 / 44(25.0)$ & & $36 / 48(75.0)$ & \\
\hline$>2 \mathrm{~cm}$ & $29 / 93(31.2)$ & & $58 / 94(61.7)$ & & $40 / 138(29.0)$ & & $71 / 148(48.0)$ & \\
\hline \multicolumn{9}{|c|}{ Tumorgrade* } \\
\hline 1 & $0 / 35(0.00)$ & $<0.0001$ & $35 / 36(97.2)$ & $<0.0001$ & $11 / 44(25.0)$ & NS & $34 / 45(75.5)$ & $<0.0001$ \\
\hline 2 & $8 / 58(13.8)$ & & $52 / 58(89.6)$ & & $20 / 60(33.3)$ & & $37 / 62(59.7)$ & \\
\hline 3 & $35 / 93(37.6)$ & & 45/94 (47.9) & & $18 / 64(28.1)$ & & $24 / 70(34.3)$ & \\
\hline \multicolumn{9}{|c|}{ Lymph nodes status } \\
\hline 0 & $15 / 106(14.2)$ & $<0.001$ & $86 / 107(80.4)$ & $<0.01$ & $18 / 76(23.7)$ & NS & $50 / 82(61.0)$ & $<0.05$ \\
\hline 1 & $14 / 62(22.6)$ & & $42 / 62(67.7)$ & & $16 / 38(42.1)$ & & $19 / 39(48.7)$ & \\
\hline 2 & 9/31 (29.0) & & $19 / 32(59.4)$ & & $15 / 48(31.2)$ & & $23 / 52(44.2)$ & \\
\hline 3 & $7 / 13(53.8)$ & & $8 / 13(61.5)$ & & $3 / 24(12.5)$ & & $10 / 27(37.0)$ & \\
\hline
\end{tabular}

${ }^{\ddagger} \mathrm{P}$ value obtained from Chi-square test for trend (two-tailed)

"Except lobular breast cancer

Abbreviations: $\mathrm{NS}=$ not significant 
Table 5. Predictor variables for non-sentinel lymph node metastases

\begin{tabular}{|c|c|c|c|c|c|c|c|c|}
\hline \multirow[t]{3}{*}{ Population } & \multicolumn{4}{|c|}{ Slovak } & \multicolumn{4}{|c|}{ Turkey } \\
\hline & \multicolumn{5}{|c|}{ Univariate Analysis } & \multicolumn{3}{|c|}{ Univariate Analysis } \\
\hline & No. of patients & NSLNM (n/\%) & $\mathrm{OR}(95 \% \mathrm{CI})^{\dagger}$ & $P$ value ${ }^{*}$ & No. of patients & NSLNM (n/\%) & $\mathrm{OR}(95 \% \mathrm{CI})^{\dagger}$ & $P$ value ${ }^{*}$ \\
\hline \multicolumn{9}{|c|}{ Tumor size $(\mathrm{cm})$} \\
\hline$\leq 1 \mathrm{~cm}$ & 64 & $14(21.9)$ & 1.00 & & 4 & $0(0.0)$ & & \\
\hline $1-2 \mathrm{~cm}$ & 56 & $25(44.6)$ & $2.88(1.30-6.37)$ & & 48 & $18(37.5)$ & 1.00 & \\
\hline$>2 \mathrm{~cm}$ & 94 & $64(68.1)$ & $7.62(3.66-15.9)$ & $<0.05$ & 148 & $100(67.6)$ & $3.94(2.02-7.67)$ & $<0.0001$ \\
\hline \multicolumn{9}{|c|}{ Tumor grade ${ }^{\#}$} \\
\hline 1 & 36 & $16(44.4)$ & 1.00 & & 45 & $24(53.3)$ & 1.00 & \\
\hline 2 & 58 & $24(41.4)$ & $0.88(0.38-2.04)$ & & 62 & $36(58.1)$ & $1.21(0.56-2.62)$ & \\
\hline 3 & 94 & $67(71.3)$ & $3.10(1.40-6.87)$ & $<0.001$ & 70 & $47(67.1)$ & $1.79(0.83-2.86)$ & NS \\
\hline \multicolumn{9}{|l|}{$P V I$} \\
\hline Absent & 104 & $29(27.9)$ & 1.00 & & 111 & $56(50.5)$ & 1.00 & \\
\hline Present & 110 & $77(70.0)$ & $6.03(3.34-10.9)$ & $<0.001$ & 89 & $62(69.7)$ & $2.26(1.26-4.05)$ & $<0.01$ \\
\hline \multicolumn{9}{|l|}{ Her-2 status } \\
\hline Negative & 167 & $75(44.9)$ & 1.00 & & 133 & $75(56.4)$ & 1.00 & \\
\hline Positive & 45 & $30(66.7)$ & $2.45(1.23-4.90)$ & NS & 53 & $35(66.0)$ & $1.50(0.77-2.92)$ & NS \\
\hline
\end{tabular}

type (24.1\% of all cancer), and the most common cause of cancer-related death in Turkish women [30]. Similarly, up to $18 \%$ of all cancers among women in Slovak republic belong to breast cancer with incidence rate 52.2/100,000 and mortality 15.4 deaths per 100,000 females [31]. In this cohort of two rarely evaluated ethnics we have found differences in breast cancer demographic and clinico-pathological factors indicating ethnic, racial and geographical differences. Demographic characteristic of Turkish patients showed high disease prevalence in young age, in women of elementary and academic education. This indicates that access to medical care and health education is struggling and needs more effective cancer information and support. Moreover, if low level of cancer knowledge in Turkish population was revealed [32]. Furthermore, Turkish women with breast cancer themselves or in relatives are experiencing a high level of needs, mainly psychological [33] when associated with diagnosis, treatment and follow-up. As cancer screenings and therapy is for people from some ethnically/geographically communities difficult to cope with, and educational level is the major predictive factor influencing the basic knowledge, achieving improvement will required cooperation between official government reforms and voluntary sector staff activity [34]. Therefore public health attention in Turkey needs to be directed towards the risk factors and health care facilities that impact on breast cancer development.

Turkey has been recently in a sociodemographic, cultural, and economic transformation where women living in both rural and urban areas have received little attention related to breast cancer risk. As the obstetric an gynaecological lifestyle and nutritional factors have impact on disease differences in women [35], informing health professionals and social workers about these issues is important for improving awareness in women about breast cancer risk neither in homeland, nor among residents abroad. Moreover, if there was observed high cancer prevalence in central Europe, explained by growing proportion of elderly people, lowering general mortality, early detection rate and increasing expenditures on health care. The increased burden of cancer could be than interpreted as a paradoxical effect of improving treatments and thereby survival.

Ethnical and geographical background in observed groups had an impact on clinic-pathological differences, as well. We have revealed that despite of higher tumor grade in Slovak patients incidence of axillary lymph node involvement was lower than in Turks. The factors to influence this include better ER, PgR or Her-2 profile [36,37], access to screening mammography, and early detection rate in Slovak women. Moreover, the high proportion of ER-negative, PgR-negative, Her-2-positive tumors seen in Turkish women may represent the "Her-2 cancer subtype", which has larger size, higher grade, poorer prognostic index, and higher stage resulting in recurrence, metastatic spread, and poorer outcome [38].

Persistence of wide disparities in socioeconomic status, availability of health insurance, structure of health care facilities, and health care affordability, may affect the cancer statistic in studied populations. Thus for disparities revealed in our study another explanation should be the difference in beginning of screening mammography (MMG). In Turkey, biannual MMG screening is recommended for women older 
than 50 years [39], whereas in Slovakia it starts from 40 [40]. Studies showed that MMG after 40 years can reduce mortality [41], thus lowering screening age in Slovak population may have an impact on differences showed in this study.

The last influence that can explain the disparities is a possible impact of significantly different age between the populations and possibility of hereditary breast cancer syndromes in population on cancer prevalence. Even more, if we have revealed five-times increased proportion of carcinomas in women less than 30 years in Turkish population. The results from molecular germline analysis showed that up to $15.1 \%$ of families with suspicion of familiar breast cancer demonstrated presence of a germline mutation in breast cancer predisposing genes (BRCA1, BRCA2) in Turkey women $[42,43]$, and similarly approximately $13.3-17.1 \%$ in Slovakia [44]. Therefore, based on high difference in cancer prevalence among cases $\leq 30$ years of age revealed in this study, germline mutation profile have to be considered as a part of study protocols when detailed analysis on ethnic/racial breast cancer differences will be investigated in further studies. Moreover, if breast cancer in young women is a unique biologic entity driven by unifying oncogenic signaling pathways, and is characterized by less hormone sensitivity, higher Her-2 expression, what warrants offering this poor-prognosis group of patients better preventative and therapeutic options [45].

Although this study is the first to compare clinic-pathological data between previously unstudied populations, the results can not be generalized as this was a region based recruiting protocol. Thus for further generalization of the findings the results needs to be validated by multi-centric approach.

\section{Conclusions}

The results of this study by revealing disparities in age of onset, hormone receptor status, Her-2 expression, higher tumor size, grade, aggressiveness and stage of disease suggest that natural history of the disease is reflecting racial/geographical disparity. Moreover, they provide unique information for clinicians indicating unfavorable breast cancer features/outcome seen among Turks, when working with ethnics residing outside its homeland, and low awareness of breast cancer risk factors and screening in this population.

Acknowledgements: This work was supported by grants VEGA no. $1 / 0069 / 09$ and 1/0243/12 from the Ministry of Education, Slovak republic.

\section{References}

[1] JEMAL A, BRAY F, CENTER MM, FERLAY J, WARD E, et al. Global cancer statistics. CA Cancer J Clin 2011; 61: 69-90. http://dx.doi.org/10.3322/caac.20107

[2] CHLEBOWSKI RT, CHEN Z, ANDERSON GL, ROHAN T, ARAGAKI A, et al. Ethnicity and breast cancer: factors influencing differences in incidence and outcome. J Natl Cancer Inst 2005; 97: 439-448. http://dx.doi.org/10.1093/jnci/ dij064

[3] SMIGAL C, JEMAL A, WARD E, COKKINIDES V, SMITH $\mathrm{R}$, et al. Trends in breast cancer by race and ethnicity: update 2006. CA Cancer J Clin 2006; 56: 168-183. http://dx.doi. org/10.3322/canjclin.56.3.168

[4] HUNTER CP. Epidemiology, stage at diagnosis, and tumor biology of breast carcinoma in multiracial and multiethnic populations. Cancer 2000; 88: 1193-1202. http://dx.doi. org/10.1002/(SICI)1097-0142(20000301)88:5+<1193::AIDCNCR3>3.0.CO;2-D

[5] JOHNSON ET. Breast cancer racial differences before age 40-implications for screening. J Natl Med Assoc 2002; 94: 149-156.

[6] LANTZ PM, MUJAHID M, SCHWARTZ K, JANZ NK, FAGERLIN A, et al. The influence of race, ethnicity, and individual socioeconomic factors on breast cancer stage at diagnosis. Am J Public Health 2006; 96: 2173-2178. http:// dx.doi.org/10.2105/AJPH.2005.072132

[7] HARPER S, LYNCH J, MEERSMAN SC, BREEN N, DAVIS $\mathrm{WW}$, et al. Trends in area-socioeconomic and race-ethnic disparities in breast cancer incidence, stage at diagnosis, screening, mortality, and survival among women ages 50 years and over (1987-2005). Cancer Epidemiol Biomarkers Prev 2009; 18: 121-131. http://dx.doi.org/10.1158/1055-9965. EPI-08-0679

[8] VRDOLJAKE, WOJTUKIEWICZ MZ, PIENKOWSKI T, BODOKY G, BERZINEC P, et al. Cancer epidemiology in Central, South and Eastern European countries. Croat Med J 2011; 52: 478-487. http://dx.doi.org/10.3325/cmj.2011.52.478

[9] NIELSEN SS, KRASNIK A. Poorer self-perceived health among migrants and ethnic minorities versus the majority population in Europe: a systematic review. Int J Public Health 2010; 55: 357-371. http://dx.doi.org/10.1007/s00038-010$\underline{0145-4}$

[10] AL-KURAYA K, SCHRAML P, SHEIKH S, AMR S, TORHORST J, et al. Predominance of high-grade pathway in breast cancer development of Middle East women. Mod Pathol 2005; 18: 891-897. http://dx.doi.org/10.1038/ modpathol.3800408

[11] STATISTISCHES BUNDESAMT. Statistisches Jahrbuch für die Bundesrepublik Deutschland 2007, 2007: 48. (Statistical yearbook 2007 for the Federal Republic of Germany). http: //www.destatis.de/.

[12] INSTITUTE FOR SLOVAK PEOPLE LIVING ABROAD. Proportion of Slovak people in abroad. 2007: 2. http: //www. uszz.sk.

[13] BANE AL, TJAN S, PARKES RK, ANDRULIS I, O'MALLEY FP. Invasive lobular carcinoma: to grade or not to grade. Mod Pathol 2005; 18: 621-628. http://dx.doi.org/10.1038/ modpathol.3800273

[14] ELLIS IO, SCHNITT SJ, SASTRE-GARAU X, et al. Invasive breast carcinoma. In: Tavassoli FA, Devilee P, editors. Pathology and Genetics of Tumours of the Breast and Female Genital Organs. Lyon, France: World Health Organization Classification of Tumours. IARC Press; 2003. P. 13-59. 
[15] ELSTON CW, ELLIS IO. Pathological prognostic factors in breast cancer I. The value of histological grade in breast cancer: experience from a large study with long-term follow-up. Histopathology 1991; 19: 403-410. http://dx.doi.org/10.1111/ j.1365-2559.1991.tb00229.x

[16] RIDOLFI RL, JAMEHDOR MR, ARBER JM. HER-2/neu testing in breast carcinoma: a combined immunohistochemical and fluorescence in situ hybridization approach. Mod Pathol 2000; 13: 866-873. http://dx.doi.org/10.1038/ modpathol.3880154

[17] Tian N, WILSON JG, ZHAN FB. Spatial association of racial/ethnic disparities between late-stage diagnosis and mortality for female breast cancer: where to intervene? Int J Health Geogr 2011; 10: 24. http://dx.doi.org/10.1186/1476072X-10-24

[18] BOYER-CHAMMARD A, TAYLOR TH, ANTON-CULVER $H$. Survival differences in breast cancer among racial/ ethnic groups: a population-based study. Cancer Detect Prev 1999; 23: 463-473. http://dx.doi.org/10.1046/j.15251500.1999.99049.x

[19] HINES LM, RISENDAL B, BYERS T, MENGSHOL S, LOWERY J, et al. Ethnic disparities in breast tumor phenotypic subtypes in Hispanic and non-Hispanic white women. J Womens Health 2011; 20: 1543-1550. http://dx.doi. org/10.1089/jwh.2010.2558

[20] DIGNAM JJ. Efficacy of systemic adjuvant therapy for breast cancer in African-American and Caucasian women. J Natl Cancer Inst Monogr 2001; 30: 36-43. http://dx.doi. org/10.1093/oxfordjournals.jncimonographs.a003458

[21] DU W, SIMON MS. Racial disparities in treatment and survival of women with stage I-III breast cancer at a large academic medical center in metropolitan Detroit. Breast Cancer Res Treat 2005; 91: 243-248. http://dx.doi.org/10.1007/s10549005-0324-9

[22] MCBRIDE R, HERSHMAN D, TSAI WY, JACOBSON JS, GRANN V, et al. Within-stage racial differences in tumor size and number of positive lymph nodes in women with breast cancer. Cancer 2007; 110: 1201-1208. http://dx.doi. org/10.1002/cncr.22884

[23] STREHL JD, WACHTER DL, FASCHING PA, BECKMANN MW, HARTMANN A. Invasive Breast Cancer: Recognition of Molecular Subtypes. Breast Care 2011; 6: 258-264.

[24] RAKHA EA, ELLIS IO. Modern classification of breast cancer: should we stick with morphology or convert to molecular profile characteristics. Adv Anat Pathol 2011; 18: 255-267. http://dx.doi.org/10.1097/PAP.0b013e318220f5d1

[25] TSUMAGARI K, CHIJIIWA K, NAGAI H, MAKITA M, KASUMI F, et al. Postoperative prognosis of node-negative breast cancers predicted by gene-expression profiling on a cDNA microarray of 25,344 genes. Breast Cancer 2005; 12: 166-177. http://dx.doi.org/10.2325/jbcs.12.166

[26] GALANINA N, BOSSUYT V, HARRIS LN. Molecular predictors of response to therapy for breast cancer. Cancer J 2011; 17: 96-103. http://dx.doi.org/10.1097/PPO.0b013e318212dee3

[27] KAJO K, ZUBOR P, BARTHOVA M, PLANK L. Scoring index for prediction of HER-2 status in the invasive breast carcinoma. Exp Oncol 2007; 29: 281-286.
[28] JOVICIC-MILENTIJEVIC M, TOKIC T, ZIVKOVIC N, DENCIC T. Simplified scoring system predicting HER-2 status in patients with breast carcinoma. J BUON 2011; 16: 444-449.

[29] ASPINALL PJ. The mandatory collection of data on ethnic group of inpatients: experience of NHS trusts in England in the first reporting years. Public Health 2000; 114: 254-259.

[30] HEALTH MINISTRY OF TURKEY (2002). The Most Frequent Ten Cancers in Females, 1999. http: //www.saglik.gov. tr/extras/istatistikler/apk2001/092.htm

[31] ONDRUSOVA M, MUZIK J, DURDIK S, ONDRUS D. Longterm trends in the development of the epidemiology of breast cancer in the Slovak and Czech Republic with reference to applied screening and international comparisons. Neoplasma 2012; 59: 70-78. http://dx.doi.org/10.4149/neo 2012009

[32] CETINGOZ R, KENTLI S, URUK O, DEMIRTAS E, EYILER F, et al. Turkish peoples knowledge of cancer and attitudes toward prevention and treatment. J Cancer Educ 2002; 17: 55-58.

[33] ERCI B, KARABULUT N. Appraising the self-assessed support needs of Turkish women with breast cancer. Eur J Cancer Care 2007; 16: 137-143. http://dx.doi.org/10.1111/j.1365$\underline{2354.2006 .00721 . x}$

[34] LANCELEY A, COX CL. Cancer information and support needs of statutory and voluntary sector staff working with people from ethnically diverse communities. Eur J Cancer Care 2007; 16: 122-129. http://dx.doi.org/10.1111/j.13652354.2006.00719.x

[35] CEBER E, SOGUKPINAR N, MERMER G, AYDEMIR G. Nutrition, lifestyle, and breast cancer risk among Turkish women. Nutr Cancer 2005; 53: 152-159. http://dx.doi. org/10.1207/s15327914nc5302 4

[36] DUNNWALD LK, ROSSING MA, LI CI. Hormone receptor status, tumor characteristics, and prognosis: a prospective cohort of breast cancer patients. Breast Cancer Res 2007; 9: R6. http://dx.doi.org/10.1186/bcr1639

[37] BEEGHLY-FADIEL A, KATAOKA N, SHU XO, CAI Q, DEMING SL, et al. Her-2/neu amplification and breast cancer survival: results from the Shanghai breast cancer study. Oncol Rep 2008; 19: 1347-1354.

[38] AL-AZAWI D, LEONG S, WONG L, KAY E, HILL AD, et al. HER-2 positive and p53 negative breast cancers are associated with poor prognosis. Cancer Invest 2011; 29: 365-369. http://dx.doi.org/10.3109/07357907.2011.584586

[39] THE TURKISH MINISTRY OF HEALTH (2004). The national breast cancer screening standards for women. http: //www. saglik.gov.tr

[40] THE SLOVAK MINISTRY OF HEALTH (2007). Z.z. 661/2007, p.5166. http: //www.zbierka.sk/zz/predpisy/ default.aspx?PredpisID=207945\&FileName $=$ zz07-00661 0207945\&Rocnik=2007

[41] NORMAN SA, RUSSELL LOCALIO A, WEBER AL, COATES RJ, ZHOU L, et al. Protection of mammography screening against death from breast cancer in women aged 40-64 years. Cancer Causes Control 2007; 18: 909-918. http://dx.doi. org/10.1007/s10552-007-9006-8

[42] YAZICI H, BITISIK O, AKISIK E, CABIOGLU N, SAIP P, et al. BRCA1 and BRCA2 mutations in Turkish breast/ovarian 
families and young breast cancer patients. Br J Cancer 2000; 83: 737-742. http://dx.doi.org/10.1054/bjoc.2000.1332

[43] MANGUOCLU E, GURAN S, YAMAC D, COLAK T, SIMSEK M, et al. Germline mutations of BRCA1 and BRCA2 genes in Turkish breast, ovarian, and prostate cancer patients. Cancer Genet Cytogenet 2010; 203: 230-237. http://dx.doi. org/10.1016/j.cancergencyto.2010.07.125

[44] KONECNY M, MILLY M, ZAVODNA K, WEISMANOVA E, GREGOROVA J, et al. Comprehensive genetic charac- terization of hereditary breast/ovarian cancer families from Slovakia. Breast Cancer Res Treat 2011; 126: 119-130. http:// dx.doi.org/10.1007/s10549-010-1325-X

[45] ANDERS CK, HSU DS, BROADWATER G, ACHARYA CR, FOEKENS JA, et al. Young age at diagnosis correlates with worse prognosis and defines a subset of breast cancers with shared patterns of gene expression. J Clin Oncol 2008; 26: 3324-3330. http://dx.doi.org/10.1200/JCO.2007.14.2471 